\title{
Electronic Systems Training Development for Automotive Technicians
}

\author{
Asep Setiadi ${ }^{\mathrm{a}, 1}$, Chris Timotius ${ }^{\mathrm{a}, 2}$ \\ ${ }^{a}$ Faculty of Technology and Vocational Education \\ Indonesia University of Education, Bandung, INDONESIA \\ ${ }^{1}$ asepsetiadi_upi@yahoo.co.id, ${ }^{2}$ christimo011@yahoo.com
}

\begin{abstract}
Bandung, West Java Indonesia is one of the most popular city for tourism, travellers, and culinary. Many people visit Bandung by planes, by trains, by motorcycles and most of them by car. Every week end around 50,000 to 60,000 automobiles came into the city center of Bandung and other areas around the city and other places as well. The problem for travellers and peoples in Bandung who use automobile is rather difficult to find good quality automobile services workshop. One factor caused this problem is a lack of competence of the automotive technicians. There are certain training deficiencies in electronic systems for modern automotive. The purpose of this paper is to show reasons, problems and on what conditions the electronic system training for automotive technicians in Bandung city can be developed successfully, it's also shown some subject matters have to be learned and practiced by the technicians. The conclusions show that success of this electronics system training development can only be achieved on the basis collaboration of all players in the field, as enterprises and employees, social partners, provider of training and education and public authorities.
\end{abstract}

Index Terms - electronic systems, automotive, lack of competences, training, development.

\section{Introduction}

Automobile started out as a simple mechanical beast. It moved people and things with little regard to the environment, safety and comfort. Through the years these concerns have provided the impetus for design change. One area that has affected automobile design the most is the same area that has greatly influenced the rest of our lives, electronics.

Today's automobiles are sophisticated electronically controlled machines. To provide comfort and safety while being friendly to the environment, today's automobiles use the latest developments of many different technologies: mechanical and chemical engineering, hydraulics, refrigeration, pneumatics, physic and of course, electronics.

An understanding of electronics is a must for all automotive technicians. The needed level of understanding is not that of an engineer, rather, technicians need a practical understanding of electronics. In addition to having the mechanical skills needed to remove, repair and replace faulty or damage components, today's technicians also must be able to diagnose and service complex electronic systems. Computers and electronic devices are used to control the operation of an engine. Because of these controls, today's automobiles use less fuel, perform better and run cleaner than those in the past.

Electronic controls also are used in nearly all systems of an automobile. The number of electronically controlled systems on cars increased each year. There are many reasons for the heavy insurgence of electronics into automobiles.
Electronics are based on electricity and electricity moves at the speed of light. This means the operation of the various systems can be monitored and changed very quickly.

Electronic components have no moving parts, are durable, do not require periodic adjustments and very light. All of these allow today's automobiles to be more efficient, cleaner, safer and better performing than vehicles of the past. The application of electronics has also led to the success of hybrid vehicles. A hybrid vehicle has two separate sources of power. Those power sources can work together to move the vehicle or can power the vehicle on their own. Today's hybrid vehicles are moved by electric motors and / or a gasoline engine. Hybrid vehicles are complex machines and who all work on them must be properly trained.

The design of today's automobiles is also influenced by legislation. Throughout history, automobile manufacturers have been required to response to new law designed to make automobiles safer and cleaner-running. In response to these laws, new systems and components are introduced. Anyone desiring to be a good technician must regularly update his or her skills to keep up with the technology. Many countries have laws that require owners to have their vehicles exhaust tested on an annual basis. Today's automotive technician must be able to find the cause of test failures and correct them.

\section{The Need for Quality Service}

The need for good technicians continues to grow. Currently there is a great shortage of qualified automotive technicians. This means there are, and will be, excellent carrier opportunities for good technicians. Good technicians are able to diagnose and repair problem in today's automobiles. Car owners demand that when things go wrong, they should "be fixed right the first time". The primary reason some technicians are unable to fix a particular problem is simply that they cannot find the cause of the problem. Today's vehicles are complex and a great amount of knowledge and understanding is required to diagnose them. Today's technicians must have good diagnostic skills. Technicians who can identify and solve problems the first time the vehicle is brought into the shop are wanted by the industry and have many excellent career opportunities [1].

\section{The Need for On-going Service}

Electronic controls have not eliminated the need for routine service and scheduled- maintenance, in fact, they have made it more important than ever. Although electronic systems can make adjustments to compensate for some problems, a computer cannot replace worn parts. A computer cannot tighten loose belts or change dirty coolant or engine 
oil. Simple problems such as these can set off a chain of unwanted events in an engine control system.

Electronic controls are designed to help a well maintained vehicle operate efficiently. They are not designed to repair systems. Electronic systems are based on the same principles as a computer. In fact, these systems rely on a computer to control the operation of a component or system. Instead of a keyboard, automotive electronic systems rely on sensors or inputs. These send information to the computer. The computer receives the inputs and through computer logic causes a component to change the way it is operating. These control outputs are similar to your computer screen or printer.

Each automobile manufacturer recommends that certain maintenance services be performed according to specific schedule. These maintenance procedures are referred to as preventive maintenance, because they are designed to prevent problems. Scheduled preventive maintenance normally includes oil and filter changes; coolant and lubrication services; replacement of belts and hoses; and replacement of spark plugs, filters and worn electrical parts. If the owner fails to follow the recommended maintenance schedule, the vehicle's warranty might not cover problems that result. For example, if the engine fails during the period cover by the warranty, the warranty may not cover the engine if the owner does not have proof that the engine's oil was changed according to the recommended schedule.

\section{Training Needs}

Those automotive industry characteristics with steadily on-going work process innovations, require the automotive technician in terms of flexibility to cover the needs of this ever-changing world of work, the ability to cope with complex work requirements which can only be determined properly on the basis of a collaboration of all players in the field, as enterprises and employees, social partners, providers of training and education and public authorities. The fact that production processes are organized across national boundaries calls especially for a cross-national transparency of qualification requirements and training needs [2].

Automotive technician can receive training in formal school settings, in Indonesia, technical and vocational upper secondary schools ( "Sekolah Menengah Kejuruan" / SMK). Completion the upper secondary schools allow student to enter universities, leading to higher education degrees. Technical and vocational degrees are also available from academies, polytechnics, colleges and universities [3].

\section{Student work experiences}

Job shadowing program: In this program student follow an experienced technician or service writer. The primary program objective is to expose student to the 'real world', to see what it takes to be a successful technician or service writer. By job shadowing, student will also become familiar with the total operation of a service department.

Mentoring program: This program has the lowest participation rate of all these programs but can be one of the most valuable. In a mentoring program, student has someone who is successful to use as an expert. The mentor has agreed to stay in contact with the student, to answer questions, and to encourage him or her. When student has a good mentor, he or she has someone who may able to explain things a little differently than the way things are explained in class. A mentor may also be able to give real life examples of why some of the things student needs to learn are important.

Cooperative Education: This type of program is typically 2 years in length. One year is spent in school and the other in a dealership or service facility. This does not mean that one solid year is spent in school, rather student spend 8 to 12 weeks at school, and then work for 8 to 12 weeks. The switching back and forth continues for 2 years. Not only student earns an hourly wage while he or she is working, he or she also earns credit toward his or her degree or diploma. While at work, student gets a chance to practice and perfect what he or she learned in school. Student experiences at work are carefully coordinated with his or her experiences at school; therefore, it is called a cooperative program industry cooperates with education. Examples of this type of program are the Chrysler CAPS, Ford ASSET, and Toyota T-Ten.

Apprenticeship Program: Similar to a cooperative education program, an apprenticeship program combines work experience with education. The primary difference between the two programs is that in an apprenticeship program students attend classes in the evening after completing a day's work. During this rigorous training program, student receives a decent hourly wage and plenty of good experience. Students start the program as helper to an experienced technician and can begin to do more on his or her own as he or she progress through the program. Most apprenticeship program takes 2 years to complete. Automobile manufacturers and dealers often sponsor these programs.

Part-Time Employment: The success of this experience depends on the students and their drive to learn. Working part-time will bring him or her good experience, some income, and a good start in getting a great full-time position after he or she has completed school. The best way to approach this is to find a position and service facility that will allow the students to grow. He or she need to start at a right level and be able to take on more difficult tasks when he or she is ready. The most difficult challenge when working part-time is to keep up with their education while they are working. Many time works may get in the way, but if they want to learn, they will find a way to fit their educational needs around their work schedule.

Postgraduate Education: A few manufacturer programs are designed for graduates of postsecondary schools. These programs train individuals to work on particular vehicles. For example BMW's Service Technician Education Program (STEP) is a scholarship program for the top graduates of automotive postsecondary schools. Students in the program apply what they learned in their 2-year program and learn to diagnose and service BMW products. BMW says this program is the most respected and intense training program of its kind in the world.

\section{The Need for Continous Learning.}

Training in automotive technology and service does not end with graduation also nor does the need to read end. A professional technician constantly learns and keeps up to date. In order to maintain the technician images as a professional and to keep his or her knowledge and skills up to date, he or she need to do what he or she can to learn new 
things. He or she need to commit himself or herself to lifelong learning. There are many ways in which the technician can keep up with the changing technology. Short course on specific systems or changes are available from the manufacturers and a number of companies that offer formal training, such as such as Federal Mogul, NAPA, AC Delco. There are also several on-line courses available. It is wise to attend update classes as soon as they can. If they wait too long, they may have difficult time catching up with the everchanging technologies. In addition to taking classes, the technician can learn by reading automotive magazines or the newest editions of automotive textbooks. A good technician takes advantage of every opportunity to learn.

\section{National Competence Standards and Proffesional Certification.}

In USA, The National Institute for Automotive Service Excellence (ASE) actively promotes professionalism within the industry. It's voluntary certification program for automotive technicians and master auto technician helps guarantee a high level of quality service.

In Indonesia, a workgroups with participation of representative of professional associations and companies coordinated by National Professional Certification Agency ( Badan Nasional Sertifikasi Profesi- BNSP ) develop Indonesian Work Competence Standards ( Standar Kompetensi Kerja Nasional Indonesia - SKKNI ). BNSP with their corresponding institutions at the provincial level the Coordination Agencies for Professional Certification (Badan Koordinasi Sertifikasi Profesi - BKSP ) also responsible for development the framework for competence certification against SKKNI. The function of BKSP is to coordinate all stakeholders of professional certification at the provincial level, to drive the application of professional certification and the creation of Professional Certification Institute ( Lembaga Sertifikasi Profesi - LSP) as well as the recruiting of assessors. LSP are often run by training institutes, professional associations or educational institutions. LSP need a certification by BNSP, and also the assessors who do the certification work, need an accreditation by BNSP [4].

\section{List of Subject Matters and their objectives for the electronics system training development for automotive technician}

Basics of electrical systems: [5].

- Explain the basic principles of electricity.

- Define the terms normally used to describe electricity.

- Use Ohm's law to determine voltage, current, and resistance.

- List the basic types of electrical circuits.

- Describe the differences between a series circuit and a parallel circuit.

- Name the various electrical components and their uses in electrical circuits.

- Describe the different kinds of automotive wiring.

General electrical system diagnostics and service:

- Describe the different possible type of electrical problems.
- Read electrical automotive diagrams.

- Perform trouble shooting procedures using meters, test lights, and jumper wires.

- Describe how each of the major types of electrical test equipment are connected and interpreted.

- Explain how to use a digital multi-meter (DMM) for diagnosing electrical and electronic systems.

- Explain how to use an oscilloscope for diagnosing electrical and electronic systems.

- Test common electrical components.

- Use wiring diagram to identify circuits and circuit problem.

- Diagnose common electrical problems.

- Properly repair wiring and connectors.

Batteries:

- Describe how a battery works

- List the precautions that must be adhered to when working with or around batteries.

- Describe the basic construction of an electrochemical cell.

- Explain how electrochemical cells can be connected to increase voltage and current.

- Explain the different methods used to recharge a battery.

- List and describe the various ways a battery may be rated.

- List and describe the various types of batteries according to their chemistries that may be used in automobiles.

- List the precautions that must be adhered to when working with or around high voltage systems.

- Describe the construction and operation of lead-acid battery.

- Describe the various types of lead-acid batteries that are available today.

- Describe the basic services and testing procedures for a lead-acid battery.

- Describe the construction and operation of a nickelmetal hydride battery.

- Describe the construction and operation of a lithiumbased battery.

Starting And Traction Motor Systems:

- Describe the basic operation of all electric motors.

- Identify the major parts of a DC motor.

- Explain the purpose of the starting system.

- Describe the purpose and major components of the starting and starter control circuits.

- Describe the different types of magnetic switches and starter devices.

- Describe the different types of starting motors used in today's vehicle.

- Inspect and test starter relays and solenoids and the switches, connectors, and wires of starter control circuits.

- Perform starter circuit voltage drop tests and the starter current draw test.

- Disassemble, clean, inspect, test, repair and reassemble a starting motor. 
- Explain the basic operation of an AC motor.

- Understand the characteristics of three-phase AC voltage and describe the operation of a three-phase AC motor.

- Explain the purpose of a controller in a motor circuit.

\section{Charging Systems:}

- Explain the purpose of the charging system

- Identify the major components of the charging systems.

- Explain the purposes of the major parts of an AC generator.

- Explain half- and full-wave rectification and how they relate to $\mathrm{AC}$ generator operation.

- Identify the different types of AC voltage regulators.

- Describe the two types of stator windings.

- Explain the features enabled by the use of a starter / generator unit.

- Perform charging system inspection and testing procedures using electrical test equipment.

\section{Ignition Systems:}

- Name and describe the three basic types of ignition systems.

- Name the two major electrical circuits used in all ignition systems and their common components.

- Describe the operation of ignition coil, spark plugs, and ignition cables.

- Explain how high voltage is induced in the coil secondary winding.

- Describe the various types of spark timing systems, including electronic switching systems and their related engine position sensors.

- Explain the basic operation of a computer-controlled ignition system.

- Describe the operation of a distributor-based ignition system.

- Describe the operation of a distributor-less ignition system.

\section{Lighting Systems:}

- Explain the operating principles of the various lighting systems.

- Describe the different types of headlights and how they are controlled.

- Understand the function of turn, stop, and hazard warning lights.

- Know how back-up lights operate.

- Replace headlights and other burned-out bulbs.

- Explain how to aim headlights.

- Explain the purpose of auxiliary automotive lighting.

- Describe the operation and construction of the various automotive lamps.

- Diagnose lighting problems.

Electrical Instrumentation:

- Describe the two types of instrument panel display.

- Know the purpose of the various gauges used in today's vehicles and how they function.
- Describe the operation of the common types of gauges found in an instrument cluster.

- List and explain the function of the various indicators found on today's vehicles.

- List and explain the function of the various warning devices found on today's vehicles.

- Explain the basics for diagnosing a gauge or warning circuits.

\section{Electrical Accessories:}

- Know the basic operation of electric windshield wiper and washer systems.

- Explain the operation of power door locks, power windows and power seats.

- Determine how well the defroster system performs.

- Identify the components of typical radio and audio systems.

- Understand how cruise or speed control operates and the differences of various systems.

- Describe the operation of keyless entry systems.

- Identify the various security disabling devices.

- Understand the operation of the various security alarms.

Detailed Diagnosis and Sensors:

- Perform a scan tester diagnosis on various vehicles.

- Conduct preliminary checks on an on-board diagnostics system.

- Use a symptom chart to set up a strategic approach to trouble shooting problem.

- Monitor the activity of on-board system components.

- Diagnose computer voltage supply and ground wires.

- Test and diagnose switch-type input sensors.

- Test and diagnose variable resistance-type input sensors.

- Test and diagnose generating-type input sensors.

- Test and diagnose output devices (actuators).

- Perform active testy of actuators using a scan tool.

\section{Indonesia Situations}

"Kontan magazine" published in July 2014 reported Indonesia's total sales of automobile in year 2013 is 1.23 million units. Several foreign manufacturers, such as Honda, Toyota, BMW, Ford, Hyundai-KIA, Nissan, Peugeot, Daimler Benz AG, Suzuki, Mitsubishi, Mazda, Isuzu operate assembly Plant in Indonesia. This many different manufacturers- brands have given customers an extremely wide selection of vehicles to choose from. This variety also created new challenges to automotive technicians based on one simple fact: Along with the different models come different systems.

SMK (a vocational middle school) in average does not prepare for the labor market. Even Technical and Vocational Education Training (TVET) teachers say that SMK graduates are not ready for work, but ready to be trained. The reason for that most likely is a mixture of several aspects. The SMK curricula contain a relatively small share of vocational content (restricted to roughly $44.45 \%$ of the curriculum), most of the schools lack of equipment for training also they do not have up to-date software for diagnosing modern 
automobile's condition (there is usually little cooperation between school and companies). As the SMK curricula contain a relatively small share of vocational content, it's not enough space or time to catch up all electronics subject matter listed above.

The national training system stipulates the implementation of apprenticeship, which organized in a "dual form" in cooperation of companies and training centers. Directorate for Technical and Vocational Education (DTVE) set up the strategic curriculum in three months in industry for the second year and three months in industry for the third year. Total six months in industry [6]. For a traditional or modern apprenticeship, this time span is too short. Automotive manufacturers / brand companies establishing their own qualification for automobile's technician rather than to rely on or work together with the public educations sector (TVET) and its offered program.

\section{Conclusions}

Some reasons described above explain why electronic system training for automotive technicians has to be developed:

- Formal vocational education (SMK) curricula contain a relative small share of vocational content. Curriculum 2013 for SMK ( 3 years program) for technology and design section, shown that vocational content only share $44.45 \%$ of the curriculum ( included technical drawing subject, excluded physics and chemicals subject of basic skill section $\mathrm{C} 1$ ).

- Lack of equipment for practical training

- Number and design of electronically controlled systems on cars are rapidly increased each year.

- Currently, especially in Bandung, there is a shortage of qualified automotive technicians.

To support the development of those training of electronic systems for automotive technicians, some recommendations are pointed below and need our seriously attention and follow up.

- To add number of non-formal vocational education ( Vocational Training for Automotive Technician), which, of course the vocational content share of the curriculum will be much more than vocational content share of those formal vocational education ( SMK).

- Collaboration of stake holders: Collaboration of stake holders of various origins is becoming more and more important. It encompasses public-private partnerships as well as cooperation between companies. Thru Corporate Social Responsibilities (CSR) programs [7] [8], we can encourage them to grant up to-date equipment and tools, hardware and software and work together with Government Job Training Institutes ( BLKI - Balai Latihan Kerja Indonesia) to establish modern and complete Electronic Systems Training Laboratory.

- To add automotive industries and service companies involvement in "Dual" education system with TVET. Directorate of Technical and Vocational Education of Ministry of Education and Culture has emphasized the importance of this Dual education system.

- To improve quality and quantity of Indonesia Work Competence Standards (SKKNI) and assure their relevance for the world of work. They also should be completed with a list of competence certificate which shown all the skills that the technicians have achieved. Each skill is certified by recognized body. So they will be regional and international recognized.

\section{References:}

[1] Abdullah Helmy, " The role of VET Provider in training partnerships with industry in East Java, Indonesia, proceeding of the 2 nd UPI International Conference on Technical and Vocational Education and Training, pp 1-9, Bandung, Indonesia 4-5 Desember 2012.

[2] 3s research laboratory (AT), DEKRA Akademie GmbH (DE), Lux Personal und Kommunikation (DE), Volkswagen Service Deutschland (DE), CREDU (FR), Centro Produttivita Veneto (IT), Politecnico di Torino (IT), Faculty of Social Sciences, University of Ljubljana (SL), Fundacion Laboral del Metal (ES), Vocational Education and Training Stakeholders of the Automotive Sector, www.project-vetas.eu or www.vetas.eu, Stuttgart, July 2011.

[3] UNESCO, Secondary Education Regional Information Base: Country Profile Indonesia. UNESCO Asia and Pacific Regional Bureau for Education, Bangkok, 2010.

[4] UNESCO-UNEVOC TVETipedia, TVET in Indonesia, http://www.unevoc.unesco.org, UNEVOC Centres. Article: Indonesia last changed on 03.04.2011 19:43 by Joachim Dittrich.

[5] J. Erjavec, Automotive Technology a Systems Approach, $5^{\text {th }}$ ed, Delmar, Cengage Learning, Clifton Park, NY, USA, 2010.

[6] Priowirjanto, Gatot Hari, Country Report: Vocational Education and Training in Indonesia, presented at International Conference on Vocational Education and Training in Asia Pasific Region, Seoul, Rep. Of Korea, October 18-20, 2000.

[7] J.J. Ramsden, “ The corporate responsibility of universities", Nanotechnology Perceptions 8 pp.167-170

[8] ------, Corporate social responsibility, Wikipedia, the free encyclopedia. 